\title{
Stomalı Hastalarda Dini Ritüeller
}

\author{
Aysel GÜL*, Dilek AYGİN**
}

$\ddot{O} \mathbf{z}$

Günümüzde kolorektal kanserler her geçen gün hızla artmaktadır. Hastalığın tedavisinde cerrahi, kemoterapi, radyoterapi gibi birçok yöntem kullanılmaktadır. Hastalığın cerrahi tedavisi sonrası bireylerde kalıcı ya da geçici stoma açılabilmektedir. Bu bağlamda hastalığın tedavi süreçlerine ilişkin, öngörücü ve önleyici stratejilerin benimsenmesi oldukça önemlidir. Stoma açılmasının bireyleri fiziksel, biyopsikososyal ve ruhsal açıdan etkilediği ve pek çok sorunu da beraberinde getirdiği bilinir. Bireylerin günlük ve enstrümental yaşam aktivitelerinin yanı sıra dini ritüellerini gerçekleştirmede de birtakım zorluklarla karşı karşıya kaldığı belirtilmektedir. Çalışmada, kolostomi açılan bireylerin dini ritüellerini gerçekleştirmede yaşadıkları sorunlar ile deneyimlerini ele alan çalışmaların incelenmesi amaçlanmıştır.

Anahtar Sözcükler: Kolostomi, cerrahi, din, hemşirelik.

\section{Religious Rituals in Patients with Stoma}

\begin{abstract}
Nowadays, colorectal cancers are increasing day by day. Many methods such as surgery, chemotherapy and radiotherapy are used in the treatment of the disease. After the surgical treatment of the disease, the permanent or temporary stoma can be opened in individuals. In this context, it is very important to adopt predictive and preventive strategies regarding the treatment processes of the disease. It is known that opening a stoma affects individuals physically, biopsychosocially and mentally and brings along many problems. It is stated that individuals face some difficulties in performing their religious rituals as well as in their daily and instrumental life activities. In this study, it is aimed to examine the studies dealing with the problems and experiences of individuals undergoing colostomy in performing their religious rituals.
\end{abstract}

Keywords: Colostomy, surgery, religion, nursing.

\section{Derleme Makale (Review Article)}

Geliş / Received: 20.05.2021 \& Kabul / Accepted: 01.07.2021

DOI: https://doi.org/10.38079/igusabder.937111

* Arş. Gör., Sakarya Üniversitesi, Sağlık Bilimleri Fakültesi, Sakarya, Türkiye, E-posta: ayselgul@sakarya.edu.tr ORCID https://orcid.org/0000-0002-0073-8916

** Prof. Dr., Sakarya Üniversitesi, Sağlık Bilimleri Fakültesi, Sakarya, Türkiye,

E-posta: daygin@sakarya.edu.tr ORCID https://orcid.org/0000-0003-4620-3412 


\section{Giriş}

Kolorektal kanserler, dünya çapındaki önemli morbidite ve mortalite nedenlerinden biridir. Hastalık yükü, gelişmiş ülkelerde en yüksek seyretmesine karşın, günümüzde gelişmekte olan ülkelerde de hızlı bir ivme kazandığı görülmektedir. Ancak farklı sosyoekonomik düzeydeki toplumlar arasında, hastalığın tanı aşamasına bağlı sağ kalım oranlarında önemli farklılıklar olduğu bilinmektedir . Dünya Sağlık Örgütü GLOBOCAN verilerine göre, 2020 yılında küresel düzeyde yaklaşık 19.3 milyon kişinin yeni kanser tanısı aldığı ve bu vakaların \%10’unu kolorektal kanserlerin (KK) oluşturduğu belirtilmektedir². Bununla birlikte dünya çapında öngörülen kanser nedenli 10 milyon ölümün ise \%9,4'ünden bu hastalığın sorumlu olduğu ifade edilmektedir². Hastalık, bugün Amerika Birleşik Devletleri’nde kanserden ölümlerin en yaygın ikinci nedeni olarak karşımıza çıkmaktadır. 2020 yılında yaklaşık 147.950 kişiye yeni KK tanısı konulduğu, 53.200 kişinin ise hastalığa bağlı hayatını kaybettiği belirtilmektedir3. Buna karşın, tüm vakaların ve ölümlerin yarısından fazlası, obezite, sigara, aşırı alkol tüketimi, kötü beslenme ve fiziksel hareketsizlik gibi değiştirilebilir risk faktörlerine bağlı olduğundan, bu hastalık potansiyel olarak önlenebilir kanserler arasında yer almaktadır4. Kompleks ve karmaşık bir süreç olan hastalığın tedavisine ilişkin, reaktif yöntemlerin aksine bireyselleştirilmiş, öngörücü ve önleyici stratejilerin benimsenmesi oldukça önemlidir5.

Kolon kanserli bireylerde cerrahi tedavi sonrası geçici veya kalıcı kolostomi açılmaktadır6. Stoma açılması ise, bireylerin fiziksel, biyopsikososyal ve ruhsal ihtiyaçlarını etkilediğinden kişilerde yaşam kalitesine ilişkin birtakım sorunları da beraberinde getirmektedir ${ }^{7,8}$. Endonezya'da yapılan bir çalışmada, varoluş, iç huzur, dini boyut gibi konularda hastaların manevi ihtiyaçlarının olduğu belirlenmiştir. Özellikle kalıcı kolostomili grupta bu ihtiyacın daha fazla olduğu tespit edilirken, en yüksek oranının dini boyutta $(\% 88,1)$ yaşandığı anlaşılmıştır 9 . Alwi ve arkadaşlarının kalıcı kolostomili bireylerin yaşam kalitelerine ilişkin deneyimlerini ortaya koymak amacıyla yaptıkları çalışmalarında (2018) ise, hastalara ilişkin, günlük yaşam aktiviteleri, evlilik yaşamı ve sosyal ilişkilerde kısıtlılık, mali zorluklar, kolostomi ile yaşamaya bağlı olumsuz duygular, kişilerin artan talepleri, dinlenme sırasındaki ve fiziksel ihtiyaçlardaki değişiklikler, komplikasyon yaşama düşüncesi ile kolostomi sonrası normal yaşam beklentisi içerisinde olmak gibi yedi tema belirlemişler. Sonuç olarak, bireylerin sosyal 
ilişkiler de dahil olmak üzere günlük yaşam aktivitelerinde zorluk ve kısıtlılıklar yaşadığını belirtmişlerdiriº.

Ameliyat sonrası dönemde karmaşık tanı ve tedavilere bağlı uzun süre hastanede kalma, sağlık profesyonelleriyle etkili iletişim kuramama, anksiyete ve stres ile baş edememe, rol değişiklikleri, değişen beden imajı ve bağırsak kontrolünün kaybı, kronik hastalıklar/tedavileri gibi birçok faktörün varlığının bireyin cerrahi sonrası süreci yönetmesinde ve başetmesinde etkili olduğu anlaşılmaktadır ${ }^{11,12}$. Ek olarak, ostomi cerrahisinin, bireylerin aile yaşantısı, günlük ve enstrümental yaşam aktiviteleri ve dini yükümlülüklerin yerine getirilmesinde de birtakım değişikliklere neden olduğu bilinmektediri ${ }^{13}$. Tüm bu alanlarda bireye özgü kapsamlı bakım verilmesi bu sürecin başarıyla yönetilmesini sağlayacaktır.

Din olgusu, insanların ilah ya da kutsal olan ile bağlantı kurması için gerekli olan sembolik yapılar ya da ritüeller sistemidir. Maneviyat ise kutsal ve insan aklını aşan deneyimlerle hayatın temel yönlerine cevaplar bulma, yaşamı anlamlandırma ve yaşamda anlam bulma çabasıdır ${ }^{14}$. Tıbbi müdahalelerin, bireylerin dini uygulamalarına ilişkin etkilerinin dikkate alınması, iyi bir tıbbi uygulamanın gerekliliğidir ${ }^{15}$.

Din ve maneviyat algısı, bireylerin iyilik halini sürdürme, durumla başa çıkma, tedaviyi kabul etme ve tedavi sonrası dönemde olumlu yaşam tarzı geliştirmeye ilişkin değişimlerine olanak tanımaktadır. Dolayısıyla fiziksel ve zihinsel sağlığın sağlanması ve sürdürülmesinde oldukça önemlidir ${ }^{14}$.

$\mathrm{Bu}$ derlemede, kolon kanseri ve cerrahisi sonrasında stoma açlan bireylerin, dini ritüellerini gerçekleştirmede yaşadıkları sorunları ve deneyimleri ele alan çalışma sonuçlarının incelenmesi amaçlanmıştır.

\section{Müslüman Toplumlar}

Müslüman toplumlarda bireylerin stoma açılması sonrası fiziksel, biyopsikososyal ve ruhsal açıdan yaşanabilecek olası değişikliklere ilişkin gösterecekleri tepkiler, dini çerçevede şekil almaktadır. Ceylan ve arkadaşlarının (2017) yaptıkları çalışmada elde edilen veriler bireylerin stoma açılması sonrası hayatlarında bir farklılık gelişmediği düşüncesini uyandırmıştır. Kişiler, stoma açılmasını, Tanrı'dan gelen bir durum olarak kabul etmekte ve kadere bağlamakta, bu durumu reddetmenin ise asilik olduğunu düşünmektedir. Stoma varlığını kadere bağlayan hastaların içinde bulundukları durumu 
kabul ettikleri belirlenmiştir. Aynı çalışmada bazı hastaların "Oldu. Kader... Bir daha ölmeyeceksin", "Tanrı'nın verdiğini söyledim, kabul ettim ve sonra rahatladım." gibi ifadeler kullandıkları görülmektedir ${ }^{16}$.

Ostomi cerrahisinin hastalarda, sağlıkla ilişkili yaşam kalitesi üzerindeki etkisi inançtan bağımsızdır. Ancak Müslüman toplumların batı toplumlarına kıyasla daha düşük sosyoekonomik düzeye sahip olması ve dini ibadetler için iyi düzeyde hijyen kurallarına uyulması yönündeki gerekliliği, bireylerde birtakım sorunlara neden olabilmektedir ${ }^{17}$. Holzer ve arkadaşlarının (2005) kalıcı kolostomili hastalarda sosyal ve coğrafi faktörlerin yaşam kalitesi üzerindeki etkisini inceledikleri araştırmada, yaş, cinsiyet ve eğitim durumu değişkenlerinin anlamlı bir etkiye sahip olmadığı belirlenmiştir. Ancak 11 ülkedeki 13 kurumdan alınan hastalarla yürütülen bu çok merkezli çalışmada, diğer dinlere kıyasla İslam dinine mensup olan bireylerde kalıcı kolostominin olumsuz etkilerinin daha fazla olduğu tespit edilmiştir ${ }^{18}$. Müslüman hastalarda ostomi cerrahisi sonrası sağlıkla ilişkili yaşam kalitesini etkileyen faktörleri belirlemek amacıyla yapılan bir başka çalışmada ise, Müslüman hastaların gayrimüslimlere kıyasla yaşam kalitesinin daha fazla bozulduğu; psikolojik faktörler, komplikasyonların eksik bildirilmesi, sosyal izolasyon, evlilik ilişkilerinin bozulması ve dini uygulamaların azalmasına neden olan cinsel işlev bozukluğunun yaşam kalitesinin kötüleşmesinde etkili olduğu görülmüştür ${ }^{19}$. İslam inancında; inancın ifade edilmesi, günde beş vakit farz namazı, ramazan ayında oruç tutmak, zekât vermek, hacca gitmek gibi beş temel şart yer alır ve bu dini şartlara tüm Müslümanların özen göstermesi gerekir ${ }^{17}$. Namaz Müslümanlar için temel manevi ihtiyaçlardan biridir. Bu dini ibadetin yerine getirilmesi bireylerde rahatlık duygusu sağladığı gibi, depresyon, anksiyete ve stres gibi olumsuz duyguları da azaltabilmektedir $^{20}$. Namazın özündeki dua, kişiler için iyileştirici ve sakinleştiricidir. Dua, övgü, tapma, itiraf, kutsama, rica, yas ve şükür gibi birçok duyguyu içerisinde barındırmaktadır ${ }^{21}$.

İslam dininde temizlik son derece önemlidir ve namaz kılan kişinin abdest ile oluşturulan, ritüel saflık içerisinde olması, namaz süresince bu durumu koruması beklenir. Gaz çıkarma, gaita ve idrar yapma gibi birtakım ihtiyaçların giderilmesi, bireylerin tekrar abdest almasını zorunlu kılar. İdrar ya da dışkı gibi birtakım bedensel sıvıların vücutla ya da kıyafetlerle teması saflı̆̆ın bozulması anlamına gelir ${ }^{17}$. Söz konusu stomanın varlığı, kişilerin dini ibadetlerini yerine getirmesine engel değildir ${ }^{22}$. İslam 
dininde, kişinin herhangi bir hastalık ya da tıbbi durumla karşı karşıya kalması, dini ibadetlerin uygulanması noktasında muafiyet yaratabilmektedir.23. Ancak uygun olmayan şartlarda yapılan bu dini uygulamalar (namaz, oruç, hac vb.) birtakım sorunları da beraberinde getirebilir. Örneğin, özellikle transvers ostomili bireylerde parastomal herni ve stomal prolapsus görülme oranlarının daha yüksek olduğu belirtilmektedir. Ortaya çıkan bu durumun, bireylerin namaz sırasında tekrarlayan eğilip bükülmelerine bağlı olduğu düşünüldüğünden, bireylere dua sırasında eğilmek yerine oturur pozisyonda iken başlarını eğmeleri tavsiye edilir. Sıklıkla bu önerilerin göz ardı edilmesi nedeniyle destek kemerlerinin kullanılması önerilmektedir ${ }^{22}$.

Dabirian ve arkadaşları (2011); hastaların çoğunun dini ritüellerinde herhangi bir değişiklik olmadığını, bazılarının ise kolostomi nedeniyle dini ritüellerinin bozulduğunu belirtmiş ve bir hastasının “camide namaz kılacağım zaman, ibadetlerde, dua ederken ve dini işlerimi gerçekleştirirken, beden temizliğimden endişe duyduğum için ibadet grubuna katılmaya layık değilim” şeklindeki düşüncesini dikkat çekici bulmuştur²4.

Stoma varlı̆̆ı, hastalarda mevcut ritüel saflığın bozulduğu ve ibadetlerin geçersiz sayıldığı korkusuna yol açmaktadır. Hatta bu korkunun, daha ciddi komplikasyon gelişme olasılı̆̆ına rağmen cerrahi yönteme ilişkin seçimlerde hastaları olumsuz yönde etkilediği görülmektedir ${ }^{25}$. Habib ve arkadaşları (2020), Müslümanlarda temiz olmanın namaz kılabilmenin temeli olarak görüldüğünden, stoma varlığının bir endişe kaynağı olduğu, bu bireylerin düşük hijyen algısı ve sızıntı korkusu nedeniyle dini ibadetlerini yerine getirmekten kaçındıkları ya da azalttıklarını bildirmişlerdir ${ }^{17}$. Ayrıca bağırsak ve mesane eliminasyonu mahremiyetine atfedilen yüksek değerin bireylerde stomanın kabulünü zorlaştırdığı görülmektedir. Bu bulguyu destekleyen bir çalışmada da namaz kılmayan hastaların \%71,4’ünün kendilerini kirli hissettikleri için ibadetlerini terk ettikleri bulunmuştur ${ }^{26}$. Akgül ve arkadaşlarının (2016) yaptıkları çalışmada, bireylerin günlük ve Cuma namazı sıklığını azalttıkları (sırasıyla \%25,2 ve \%22,7) ve bu ibadetleri toplu olarak gerçekleştirmeyi bıraktıkları (sırasıyla \%12 ve \%14) tespit edilmiştir. Bu duruma bireylerin temizlik algısının yarattığı endişenin neden olduğu görülmüştür. Kişilerin oruç ibadetini azaltmalarına karşın, dua etme/af dileme eylemlerinin sıklığında bir artış olduğu saptanmıştır ${ }^{27}$.

Oruç, bireyin gün doğumunda oruç tutmak için niyet etmesiyle başlayıp, yaklaşık 16 saat süren bir ibadettir ve ergenliğe ulaşan erkek ve kadın, her birey için bir zorunluluktur. 
Bu ibadetin özünde yiyecek ve içeceklerden, cinsel aktivitelerden, kötü düşünce ve davranışlardan uzak durma vardır. Oruç ibadetinin, spiritüel, sosyal ve sağlık başlıkları altında, maneviyat, ahlak ve beden sağlığına ilişkin birçok olumlu etkisi bulunmaktadır ${ }^{28}$. Her ne kadar oruç ibadeti Müslümanlar için bir zorunluluk olsa da, çocuklar, yaşlılar, hamile kadınlar, yolcular ve akut ya da kronik hastalığı olan kişiler vb. gibi bazı istisnai durumlar söz konusudur ${ }^{29,30}$. Dolayısıyla herhangi bir hastalık durumunda oruç tutulup tutulmayacağı sorusu, hekimlerin sık karşılaştığı durumlardan birisidir ve bu hasta gruplarından birini de stomalı bireyler meydana getirir. Oruç ibadeti yapılırken; ileostomili bireylerde sıvı-elektrolit dengesizlikleri, kolostomili bireylerde konstipasyon gibi bazı istenmeyen durumlar görülebilmektedir ${ }^{27}$. Hussein ve arkadaşlarının (2001) yaptıkları çalışmada, hastaların \%83’ünde oruç ibadetinin stoma bakımını etkilemediği, ancak hastaların \%17'sinde stoma bakımını olumsuz yönde etkileyecek şekilde bağırsak alışkanlıklarında değişiklikler yaşandığı tespit edilmiştir31. Çavdar ve arkadaşlarının (2013) çalışmasında, oruç tutan stomalı hastaların \%28’i rahatsızlık hissettikleri, stoma oluşturulduktan sonra oruç tutamayanların \%69'unun stomaya zarar vermekten korktukları, \%88’inin stoma açılmadan önce düzenli oruç tutarken, bu oranın stoma açılması sonrası \%44'e düştüğü, \%74,2'sinin stoma öncesinde düzenli dua etmesine karşın, stoma açılması sonrası bu oranın \%53’e düştüğü belirlenmiştir ${ }^{26}$. Bu bulguların tersine, stomalı hastalarda oruç tutmanın beslenme ve metabolik durum ve yaşam kalitesi üzerindeki etkisinin incelendiği başka bir çalışmada; kendilerini dindar olarak görmeyen grubun, Dini Yönelim Ölçeği puanı yüksek olan grup kadar oruç tutmakta istekli olduğu, oruçlu olan gruptaki bireyler arasında kalıcı stoma oranının daha fazla olduğu ve daha uzun bir süredir stomayla yaşadıkları görülmüştür. Oruçlu ve oruç tutmayan gruplar arasında beslenme belirteçlerine ilişkin laboratuvar bulguları incelendiğinde; açlık grubundaki hastaların anlamlı derecede daha sağlıklı olduğunu düşündürmüş (sadece prealbümin seviyesinde anlamlı bir azalma olmuş), yorgunluk, nefes darlığı, ağız kuruluğu, iştah kaybı, ağrı, şişkinlik ve dışkı inkontinansı gibi birtakım bulguların ve yaşam kalitesine ilişkin değişkenlerin Ramazan öncesi döneme kıyasla olumlu yönde etkilendiği, gruplar arasında anlamlı fark bulunmadığı ifade edilmiştir. Oruç tutan hastaların \%86'sı açlığın günlük yaşamını olumsuz yönde etkilemediğini, \%93’ü ise oruç tutmazlarsa üzüleceklerini belirtmişlerdirº. 
Sağlıklı, maddi ihtiyaçlarını karşılayabilen tüm Müslümanlar, hayatları boyunca bir kez Mekke'ye giderek hac ibadeti gerçekleştirmek zorundadırlar32. Bu bağlamda stoması olan bir bireyin, çevresini kirletmemek ve diğer insanları rahatsız edecek şekilde kötü koku yaymamak koşuluyla camiye girmesi ve Hac sırasında Kabe'yi tavaf etmesinde herhangi bir sakınca yoktur ${ }^{16}$. Ancak Hussein ve Fadl (2001) yaptıkları çalışmada, stoma torbasının boşaltılması ve atılmasına ilişkin zorluklar yaşanabileceği düşüncesiyle, stomalı bireylerin uzun süren seyahatlere çıkmalarını olumsuz yönde etkilediği için hastaların \%54’ünün hac ibadetini gerçekleştiremediğini ortaya koymuştur3¹.

Igbal ve arkadaşlarının (2014) kolorektal cerrah ve enterostomal uzmanı hemşirelerin Müslüman hastalardaki İslami uygulamalara ilişkin farkındalıklarını değerlendirmek amacıyla yaptıkları çalışmada cerrahların \%20’sinin, hemşirelerin ise \%11’inin ameliyat öncesi dönemde hastalarla dini uygulamaları konuşmak konusunda kararsız kaldıkları belirlenmiştir. Oruç ibadetine ilişkin olarak hemşirelerin \%52'sinin ve cerrahların \%73’ünün herhangi bir konuşma yapmadığı tespit edilmiştir. Cerrah ve hemşirelerin yaklaşık \%40’ı ise hastaların danışmanlık sürecine dini liderlerin dahil edilmesinin gerekli olmadığını belirtmiştir. Çalışmaya katılanların sadece \%3’ü tüm İslami dua pozisyonlarını doğru bilmiştir. Bu sonuç, sağlık profesyonellerinin konuya ilişkin farkındalıklarının arttırılması gerekliliğini ortaya koymaktadır33.

\section{Gayrimüslim Toplumlar}

Çok boyutlu olarak organizmayı etkisi alan spiritüalizm, kültürel alt yapıdan etkilenir. $\mathrm{Bu}$ bağlamda inanç sistemlerinin çeşitliliği önemli bir etkendir. Maneviyat olgusunun, psikolojik uyumu kolaylaştırması ve yaşam kalitesini artırabilmesi nedeniyle, bireylerin hastalık ve hastalığa ilişkin durumlarla başa çıkabilmesinde olumlu etki sağladığı görülmektedir34. Dolayısıyla benzer yanlar olsa da farklı dinlere mensup bireylerin hastalığa atfettiği anlamlar değişiklik gösterebilmektedir. Örneğin; Taocular intikam ya da birtakım talihsizliklerin hastalığa veya ölüme yol açtığına inanırlar. Bu intikam tablosunun ise daha önceki nesillerin olumsuz davranışları nedeniyle meydana geldiğini belirtirler. Budistler ise yaşamın sonsuz bir ızdırap denizi olduğunu, dini uygulamaların amacının ise bu acıyı dindirmek ve mutluluk kazanmak olduğunu ortaya koyarlar35. Kuzey Etiyopya toplumunda bireylerin hastalanma nedenlerine ilişkin inanış ve algılarının, doğaüstü (örneğin; yüce Tanrı/Allah, doğa ruhları vb), doğal (çevresel temizlik, yoksulluk, biyolojik ve psikolojik etkenler) ve toplumsal etkenler (aile desteği, 
sosyal tabuların ihlali) başlıkları altında şekillendiği görülür ${ }^{36}$. Li ve arkadaşlarının (2012) Konfüçyüsçülük inanışı, Budizm ve Taoizm dinine mensup bireylerle yaptıkları çalışmada, hastaların manevi iyi oluş düzeyleri ile psikososyal uyumları arasında önemli ölçüde bir ilişkinin olduğu tespit edilmiştir35.

Hindistan'da yapılan bir başka çalışmada ise hasta/lar dini yerlere gitmek için kendilerini iyi hissetmediklerini, bedenlerinin kirli olduğu düşüncesi nedeniyle kendilerinden utandıklarını dile getirmişlerdir. Aynı çalışmada, hasta/lar ameliyat sonrası hiç dini söylemler/ilahi söylemediklerini belirtmişlerdir. Ayrıca ameliyat öncesi dönemde her gün dini yerlere ziyaret yapan hastalar, stoma açılması sonrası kendilerini kirli ve suçlu hissettikleri için gitmediklerini söylemişlerdir. Burada hasta ostomi ile dini yerlere gitmenin suçluluk ve kısıtlılık hissine neden olduğunu ortaya koymuştur37. Hindistan'daki bir diğer araştırma, ürostomili hastaların deneyimlerini değerlendirmek amacıyla yapılmış. Bu çalışmada bazı hastalar, ürostomi nedeniyle ikinci bir şansa sahip olduklarını düşündüklerinden, maneviyat odaklı bir yaşam tarzı değişikliğine ihtiyaçları olduğunu dile getirirken, tersine bazı hastalar da ürostominin, idrarın bedene teması nedeniyle, vücut hijyenini bozduğunu ifade etmiştir. Ayrıca hastaların dua edemedikleri için oldukça stresli oldukları anlaşılmış ve "Dinimizde vücuda bir damla idrar dokunsa bile dua edilmez. Dua etmek için tamamen saf olmalıyız (Gözleri yaşlarla dolu)” şeklindeki bir hasta ifadesine de yer verilmiştir ${ }^{8}$. Amerika'da intestinal stoması olan bireylerin ruhsal yaşam kalitesinin incelendiği başka bir çalışmada ise, evli, ameliyatının üzerinden uzun yıllar geçmiş ve ileri yaştaki bireylerin yüksek ruhsal yaşam kalitesine sahip olma olasılıklarının daha fazla olduğu görülmüştür. Aynı araştırmada bazı hastaların "Her gün yataktan kalkıp gittiğim için Tanrı'ya teşekkür ederek bakıyorum", "...bacaklarmm her yerinde bu hurda... Yatak berbattı (cihaz sızdı ve tamamen yatak değişimi gerektirdi) ve o gecenin geri kalanında dua ettim, lütfen bir daha olma..." ifadelerini kullandıkları görülmüsşür39. Dolayısıyla bireylerin hastalık ve hastalık sürecinin yarattığı olumsuz birtakım duygularla spiritüel yollarla baş etmeyi seçtikleri görülmektedir. Bu bağlamda bireylerin sağlık kontrol odaklarının birbirinden farklı olduğu söylenebilir. Sağlık kontrol odakları, kendileri ya da çevrelerinde gelişen birtakım olay/davranışlarda iç ve/veya dış birtakım kontrollerin olduğunu kabul eden bir inançlar sistemidir. $\mathrm{Bu}$ sistemde dış inançları, şans, kader tarafından belirlenen rastgele beklentiler oluştururken, aile üyeleri, hekimler vb. gibi güçlü birtakım destekler ise iç 
kontrolleri meydana getirmektedir. Bu noktada, gelişen birtakım olay/durumların meydana gelmesinde farklı sistemlerin etkisi/etkilerinin olduğunu düşünen bireylerin hastalık ve sürecine ilişkin vereceği davranışsal tepkilerin farklılık göstermesi şaşırtıcı değildir ${ }^{13}$.

\section{Stomalı Hastalarda Dini Ritüellerde Bakımın Rolü}

İnsan yaşamının önemli bir yönünü oluşturan maneviyat olgusu, bireylere hastalıktan sonra iyileşme umudu verir. Bireylerin değerleri, inanç ve gelenekleri bu olgunun temelini oluşturur. Bu kavram, ruhun iç dünyasını yansıttığından her birey için özneldir. Dolayısıyla bireylerin olay ve durumlara verdikleri tepki ile yükledikleri anlam farklılık gösterir. $\mathrm{Bu}$ bağlamda kişinin hastalık ve hastalık sürecini deneyimleme algısı değişkendir. Örneğin; hasta, hastalığı Tanrı'nın ona vermiş olduğu bir ceza olarak görebilir ${ }^{16,35}$. Cerrahi operasyonların sonuçlarına ilişkin hastaların maneviyat algılarının belirlenmesi amacıyla yapılan nitel çalışmada; hastaların önemli bir kısmı, ameliyatın yaşamları için bir tehdit olduğunu ve vücutlarının bir kısmını kaybedecekleri yönünde his yaşadıklarını bildirmiştir. Hastalar Tanrı’nın müdahalesinin ameliyatların başarılı geçmesinde etkili olduğuna inanmaktadır. Dolayısıyla başarılı bir cerrahi, ilahi gücün müdahalesine bağlanmıştır. Oysaki hastaların çok az bir kısmı, cerrahinin başarılı sonuçlanmasında doktor ve hemşirelerin yetkinliklerine inandıklarına bildirmişlerdir ${ }^{40}$. Bu bağlamda hastalara her bireye özgü bütüncül hemşirelik bakımı sunulması oldukça önemlidir. Ruhsal hastalık algısının anlaşılmasında önemli bir parametrenin sıklıkla göz ardı edildiği görülmektedir41. Stoma açılmasının, bireyleri fiziksel, psikolojik, sosyal, ruhsal ve birçok açıdan etkilediği bilinmektedir. Bu noktada özellikle hastaların dini ve maneviyat ihtiyaçlarının belirlenmesi ve müdahalesi, hemşirelik bakımının önemli bir parçasıdır ${ }^{40}$. Hastaların manevi ihtiyaçlarını karşılamalarını sağlamak/kolaylaştırmak, hemşirelik bakımında manevi uygulamaları geliştirmek oldukça önemlidir. Bu ihtiyacın hastalar tarafından kolaylıkla giderilmesi noktasında terapötik iletişim kurma, birlikte dua etme, ibadetlerini gerçekleştirebilmeleri için ortam yaratma vb. gibi birçok

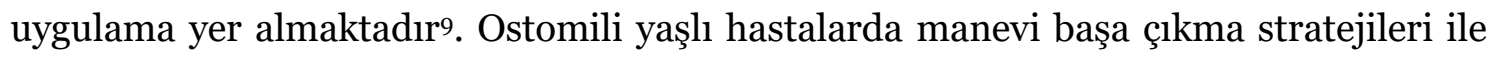
yaşam kaliteleri arasındaki ilişkiyi incelemek amacıyla yapılan araştırmada önemli sonuçlar elde edilmiştir. Bu çalışmada, ostomili hasta ve yakınları için uygun ve etkili hemşirelik bakım müdahalelerinin planlanması ve uygulanmasının, bireylerin manevi başa çıkma stratejilerini geliştireceği, mental, sosyal ve ruhsal öz yeterliliklerini 
arttıracağı ve yaşam kalitelerini iyileştireceği görülmüştür34. Hemşirelerin bu noktada önemli bir etkisinin olduğu açıktır.

\section{Sonuç}

Stoma varlı̆̆ının, bireylerde manevi/spiritüel etkilerinin sanılanın aksine oldukça fazla olduğu görülmektedir. Manevi ihtiyaçların önemli bir kısmını, din olgusu ve beraberinde getirdiği uygulamalar oluşturmaktadır. Özellikle Müslüman toplumlarda dini ibadetler konusunda yaşanan endişe ve kaygıların, bireylerin psikososyal uyum düzeyleri ve yaşam kalitelerini olumsuz yönde etkilediği anlaşılmıştır. Sağlık profesyonellerinin konuya ilişkin farkındalıklarının arttırılması holistik bakım açısından oldukça önemlidir. Dolayısıyla empatik yaklaşımla hastaların sorunlarını ifade etmelerinin sağlanması ve manevi/spiritüel konulara ilişkin stomalı bireylerin bilgilendirilmesi gerekmektedir.

Müslüman bireylerde, bu hasta grubuna ilişkin yapılan çok sayıda çalışma olmasına karşın, gayrimüslüm toplum/bireylere yönelik yapılan araştırmaların azlığı dikkat çekmektedir. Bu bağlamda farklı dinlere mensup bireylere ilişkin, hasta deneyimlerinin yer aldığı çalışmaların yapılmasına ihtiyaç vardır.

\section{KAYNAKLAR}

1. Sharma R. An examination of colorectal cancer burden by socioeconomic status: evidence from GLOBOCAN 2018. EPMA Journal. 2020;11:95-117.

2. Sung H, Ferlay J, Siegel RL, et al. Global Cancer Statistics 2020: GLOBOCAN estimates of incidence and mortality worldwide for 36 cancers in 185 countries. $C A$ Cancer J Clin. 2021;71(3):209-249.

3. Siegel RL, Miller KD, Sauer AG, et al. Colorectal cancer statistics, 2020. CA Cancer J Clin. 2020;70(3):145-164.

4. Mohd Y, Balasubramanian B, Meyyazhagan A, et al. Extricating the association between the prognostic factors of colorectal cancer. Journal of Gastrointestinal Cancer. 2020. doi: 10.1007/s12029-020-00535-4. Online ahead of print.

5. Janssens JP, Schuster K, Voss A. Preventive, predictive, and personalized medicine for effective and affordable cancer care. EPMA Journal. 2018;9:113-123. 
6. de Almeida Silva K, Duarte AX, Cruz AR, de Araújo LB, das Graças Pena G. Time after ostomy surgery and type of treatment are associated with quality of life changes in colorectal cancer patients with colostomy. PLoS One. 2020;15(12):1-17.

7. Jansen F, van Uden-Kraan CF, Braakman JA, van Keizerswaard PM, Witte BI, Verdonck-de Leeuw IM. A mixed-method study on the generic and ostomy specific quality of life of cancer and non-cancer ostomy patients. Support Care Cancer. 2015;23(6):1689-97.

8. Näsvall P, Dahlstrand U, Löwenmark T, Rutegård J, Gunnarsson U, Strigård K. Quality of life in patients with a permanent stoma after rectal cancer surgery. Qual Life Res. 2017;26(1):55-64.

9. Mozaike R, Isabella C, Praptiwi A. Spiritual needs of patients with a colostomy in a public hospital. The Journal of Nursing Care. 2018;1(2):91-100.

10. Alwi F, Setiawan, Asrizal. Quality of life of persons with permanent colostomy: a phenomenological study. Journal of Coloproctology. 2018;38(4):295-301.

11. Sharma J, Singh M. An exploratory study to assess the physical, psychological problems and coping mechanisms in colostomy patients in selected hospital of Jaipur city. International Journal of Health Sciences \& Research. 2015;5(5):252263.

12. Mallick U. Stress and coping mechanism among colostomy patients. International Journal Of Multidisciplinary Educational Research. 2020;9(4):129-138.

13. de Oliveira Moreira CN, Marquesa CB, Pereira da Silva MAP, Pinheiro FAM, Salomé GM. Association of sociodemographic and clinical factors with spirituality and hope for cure of ostomized people. J. Coloproctol. (Rio J.). 2016;36(3):162-172.

14. Simão TP, Caldeira S, de Carvalho EC. The Effect of prayer on patients' health: systematic literature review. Religions. 2016;7(1):1-11.

15. Jagues H. GMC publishes new version of Good medical practice. BMJ. 2013;346. doi:10.1136/bmj.f2oo3.

16. Ceylan H, Vural F. Living with stoma - a phenomenological study. J Nurs Res Pract. 2017;1(1):6-12. 
17. Habib A, Connor MJ, Boxall NE, Lamb BW, Miah S. Improving quality of life for Muslim patients requiring a stoma: A critical review of theological and psychosocial issues. Surgical Practice. 2020;24:29-36.

18. Holzer B, Matzel K, Schiedeck T, et al. Do geographic and educational factors influence the quality of life in rectal cancer patients with a permanent colostomy? Dis Colon Rectum. 2005;48(12):2209-2216.

19. Iqbal F, Kujan O, Bowley DM, Keighley MRB, Vaizey CJ. Quality of life after ostomy surgery in muslim patients: a systematic review of the literature and suggestions for clinical practice. $J$ Wound Ostomy Continence Nurs. 2016;43(4):385-91.

20. Hariawan H, Soedirham O, Bakar A. Individual coaching during hospitalization improves the spirituality of muslim patients. Jurnal Ners. 2019;14(1):87-91.

21. Amini K, Sahebnasagh A, Mojtahedzadeh M. The influence of prayer on critical patients admitted to the intensive care unit. Critical Comments in Biomedicine. 2020;1(1):1-4.

22. Hibbert D. View from here caring for persons with ostomies in Saudi Arabia. $J$ Wound Ostomy Continence Nurs. 2016;43(4):398-399.

23. Din İşleri Yüksek Kurul Başkanlığı. https://kurul.diyanet.gov.tr/. Erişim tarihi 11 Kasim 2020.

24. Dabirian A, Yaghmaei F, Rassouli M, Zagheri Tafreshi M. Quality of life in ostomy patients: a qualitative study. Patient Preference and Adherence. 2011;5:1-5.

25. Miah S, Mangera A, Osman NI, Venugopal S, Catto J, Rosario D. Islam and the urinary stoma: a contemporary theological and urological dilemma. European Urology Focus. 2019;5(2):301-305.

26. Çavdar İ, Özbaş A, Akyüz N, Yıldız Fındık Ü, Kutlu Y. Religious worship in patients with abdominal stoma: praying and fasting during ramadan. International Journal Of Nursing Sciences. 2013;6(3):516-521.

27. Akgül B, Karadağ A. The effect of colostomy and ileostomy on acts of worship in the Islamic Faith. $J$ Wound Ostomy Continence Nurs. 2016;43(4):392-397. 
28. Khan MMA, Nor NM, Mamat NM, Mohd-Shukri NA, Abu Bakar WAM. Fasting in Islam: a combination of spiritual elevation and prevention of diseases. IMJM. 2018;17(2):107-112.

29. Bunyamin M. Adam Al-Haraj: A rukhshah application in the implementation of Islamic law in modern society life. Al-'Adalah. 2018;15(1):101-124.

30. Altuntas YE, Gezen FC, Sahoniz T, Kement M, Aydin H, Sahin F. Ramadan fasting in patients with a stoma: a prospective study of quality of life and nutritional status. Ostomy Wound Manage. 2013;59(5):26-32.

31. Hussein AM, Fadl SA. Quality of life in Egyptian stoma patients. Egyptian Journal of Surgery. 2001;20(3):597-607.

32. Moufahim M, Lichrou M. Pilgrimage, consumption and rituals: Spiritual authenticity in a Shia Muslim pilgrimage. Tourism Management. 2019;70:322-332.

33. Iqbal F, Batool Z, Varma S, Bowley D, Vaizey C. A survey to assess knowledge among international colorectal clinicians and enterostomal therapy nurses about stoma-related faith needs of Muslim patients. Ostomy Wound Manage. 2014;60(5):28-37.

34. Mohammadi M, Esmaeili R, Fani M. Review of the correlation between religion coping strategy and quality of life in intestine cancer in patients with ostomy. Journal of Advanced Pharmacy Education \& Research. 2019;9(S2):111-116.

35. Li CC, Rew L, Hwang SL. The relationship between spiritual well-being and psychosocial adjustment in Taiwanese patients with colorectal cancer and a colostomy. J Wound Ostomy Continence Nurs. 2012;39(2):161-169.

36. Kahissay MH, Fenta TG, Boon H. Beliefs and perception of ill-health causation: a socio-cultural qualitative study in rural North-Eastern Ethiopia. BMC Public Health. 2017:26;17(1):124.

37. Kaur SK, Das K, Gupta R. Psychosocial experiences of the patients with colostomy/ileostomy: a qualitative study. Indian Journal of Social Psychiatry. 2014;30(1-2):28-34. 
38. Sharma M, Kaur S, Seth A, Singh P. Living with urostomy: patient's perspective. Indian Journal of Public Health Research \& Development. 2020;11(6):35-40.

39. Baldwin CM, Grant M, Wendel C, et al. Influence of intestinal stoma on spiritual quality of life of U.S. veterans. $J$ Holist Nurs. 2008;26(3):185-94.

40. Atinyagrika Adugbire B, Aziato L. Surgical patients' perception of spirituality on the outcome of surgery in Northern Ghana. Journal of Holistic Nursing. 2020;38(1):19-29.

41. Melhem GAB, Zeilani RS, Zaqqout OA, Aljwad Aİ, Shawagfeh MQ, Al- Rahim MA. Nurses' perceptions of spirituality and spiritual care giving: a comparison study among all health care sectors in Jordan. Indian Journal of Palliative Care. 2016;22(1):42-49. 